\title{
Article \\ Rice PIN Auxin Efflux Carriers Modulate the Nitrogen Response in a Changing Nitrogen Growth Environment
}

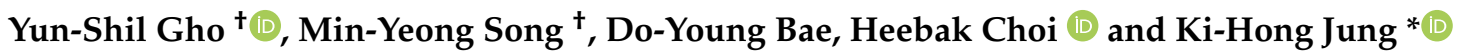 \\ Graduate School of Biotechnology \& Crop Biotech Institute, Kyung Hee University, Yongin 17104, Korea; \\ koyoong@khu.ac.kr (Y.-S.G.); min2187@khu.ac.kr (M.-Y.S.); dybae323@khu.ac.kr (D.-Y.B.); \\ backy28@khu.ac.kr (H.C.) \\ * Correspondence: khjung2010@khu.ac.kr; Tel.: +82-31-201-3474 \\ + These authors contributed equally.
}

check for updates

Citation: Gho, Y.-S.; Song, M.-Y.; Bae, D.-Y.; Choi, H.; Jung, K.-H. Rice PIN Auxin Efflux Carriers Modulate the Nitrogen Response in a Changing Nitrogen Growth Environment. Int. J. Mol. Sci. 2021, 22, 3243. https:// doi.org/10.3390/ijms22063243

Academic Editor: Vicent Arbona

Received: 2 March 2021

Accepted: 18 March 2021

Published: 23 March 2021

Publisher's Note: MDPI stays neutral with regard to jurisdictional claims in published maps and institutional affiliations.

Copyright: (c) 2021 by the authors. Licensee MDPI, Basel, Switzerland. This article is an open access article distributed under the terms and conditions of the Creative Commons Attribution (CC BY) license (https:// creativecommons.org/licenses/by/ $4.0 /)$.

\begin{abstract}
Auxins play an essential role in regulating plant growth and adaptation to abiotic stresses, such as nutrient stress. Our current understanding of auxins is based almost entirely on the results of research on the eudicot Arabidopsis thaliana, however, the role of the rice PIN-FORMED (PIN) auxin efflux carriers in the regulation of the ammonium-dependent response remains elusive. Here, we analyzed the expression patterns in various organs/tissues and the ammonium-dependent response of rice PIN-family genes (OsPIN genes) via qRT-PCR, and attempted to elucidate the relationship between nitrogen $(\mathrm{N})$ utilization and auxin transporters. To investigate auxin distribution under ammonium-dependent response after $\mathrm{N}$ deficiency in rice roots, we used DR5::VENUS reporter lines that retained a highly active synthetic auxin response. Subsequently, we confirmed that ammonium supplementation reduced the DR5::VENUS signal compared with that observed in the N-deficient condition. These results are consistent with the decreased expression patterns of almost all OsPIN genes in the presence of the ammonium-dependent response to $\mathrm{N}$ deficiency. Furthermore, the ospin $1 b$ mutant showed an insensitive phenotype in the ammonium-dependent response to $\mathrm{N}$ deficiency and disturbances in the regulation of several $\mathrm{N}$-assimilation genes. These molecular and physiological findings suggest that auxin is involved in the ammonium assimilation process of rice, which is a model crop plant.
\end{abstract}

Keywords: rice; auxin; auxin efflux carrier; ammonium-dependent response; ammonium assimilation; ospin1b mutant

\section{Introduction}

Auxins play an essential role in regulating plant growth and adaptation to abiotic stresses, and their spatial distribution depends largely on the polar localization of the PIN-FORMED (PIN) auxin efflux carrier family. The PIN family plays a role in directing intercellular auxin flow and mediating the auxin-regulated developmental processes [1]. Arabidopsis carries eight members of this protein family, and the AtPIN proteins are divided into two types: one has a long hydrophilic loop ("long PIN proteins") and the other contains a short hydrophilic loop ("short PIN proteins"). Both types have been reported to participate in various developmental processes [2-4]. AtPIN1-4 and AtPIN7, with the long hydrophilic loop, are located in the plasma membrane and are involved in root development and apical shoot establishment [5,6]. AtPIN5 and AtPIN8 are localized in the endoplasmic reticulum and play roles in the homeostasis of intracellular auxins [7,8]. Interestingly, AtPIN6 is localized in both plasma membranes and the endoplasmic reticulum [9]. Homologs are also found in rice, which has 12 potential PIN family members, including: four PIN1s and one PIN2, which belong to the long PINs; three PIN5s and one PIN8, which belong to the short PINs; and three monocot-specific PINs (PIN9, PIN10a, and PIN10b) [10]. The rice PIN genes are involved in hormone signaling and abiotic stress responses [11-13]. However, our current knowledge of the auxin signaling pathway associated with the PIN 
family is almost entirely based on the results of research on the PIN-family genes of the eudicot Arabidopsis thaliana. Research on PINs as auxin transporters related to nutrients, especially $\mathrm{N}$, is scarce.

$\mathrm{N}$ is one of the major nutrients in plants and is essential for normal growth. The $\mathrm{N}$ supply for plant growth is mainly obtained from fertilizer supplementation; however, nitrogen use efficiency is quite low, and excess nitrogen causes environmental pollution, including water and soil contamination and an increase in production costs. Plants absorb $\mathrm{N}$ from the soil in the form of nitrate $\left(\mathrm{NO}_{3}{ }^{-}\right)$and ammonium $\left(\mathrm{NH}_{4}{ }^{+}\right)$via the roots using ammonium transporters (AMTs). There are at least 12 putative OsAMT-like genes in rice further divided to five classes (OsAMT1-5) [14]. OsAMT1 class members are characterized as high affinity transport systems (HAT), while the other four classes are characterized as low affinity transport systems (LAT) [15,16]. OsAMT1;1 is constitutively expressed in the leaves but is stimulated in the roots under ammonium supply. The expression of OsAMT1;2 is both root-specific and ammonium-inducible, whereas the expression of OsAMT1;3 is root-specific but is suppressed under ammonium supply [17,18]. The $\mathrm{NH} 4^{+}$ is toxic and so it needs to be rapidly assimilated by the Gln synthetase (GS)/Glu synthase (GOGAT) pathway; this process requires energy, a reductant, and C skeletons in the form of 2-oxoglutarate $(2-\mathrm{OG})[19,20]$. Rice has two types of GS: three homologous genes for cytosolic GS1 (OsGS1;1, OsGS1;2 and OsGS1;3) and one chloroplastic GS2 gene (OsGS2), which carries out the first step in inorganic $\mathrm{N}$ incorporation into amino acids by transferring ammonium to Glu to form Gln [21]. OsGS1;1 was found to be highly expressed in all tested organs in leaf blades, while OsGS1;2 and OsGS1;3 were expressed mainly in the roots and spikelet, respectively [22]. OsGS2 is the major GS isoform and is located in mesophyll cell chloroplasts. The GOGAT performs the second step in the GS/GOGAT cycle and catalyzes the reductant-dependent conversion of Gln and 2-OG to two molecules of Glu. Rice has two NADH-types (two GOGATs and one Fd-GOGAT) [23]. OsNADH-GOGAT1 is expressed in the epidermis of the root after the supply of $\mathrm{NH}^{+}$, and is primarily involved in ammonium assimilation in the root [24]. Recently, it has also been reported that dual activation of OsAMT1;2 and OsGOGAT1 improves crop agriculture traits, providing better grain filling without yield penalties in paddy conditions and better grain yield and $\mathrm{N}$ content when growing plants under $\mathrm{N}$ restriction [25]. Several studies aimed at improving the N-use efficiency have been reported, but the practical application of this knowledge remains fairly limited.

Recently, auxins have been shown to play important roles in plant adaptation in response to the fluctuating availability of usable N [26]. Moreover, OsPIN1b has been shown to be involved in seminal root elongation by regulating root apical meristem activity under low-nutrient conditions [27]. However, little is known about the role of OsPINs at the transcriptional level under N-supplementation conditions. Therefore, the functional involvement of the PIN-family genes in $\mathrm{N}$ utilization is a particularly interesting topic for further study.

In the present study, we examined the functional roles of rice PIN family members through a diverse spatial expression analysis using qRT-PCR and a meta-expression analysis of data from 983 Affymetrix arrays [28]. We performed a time-course experiment to examine the expression patterns of the OsPINs gene in response to $\mathrm{N}$ availability. After supplementation with $\mathrm{N}$, following long-term $\mathrm{N}$ deprivation, almost all OsPIN-family genes were substantially downregulated. These results are consistent with the decreased expression pattern of the DR5::VENUS reporter lines. The DR5::VENUS reporter lines retain a highly active synthetic auxin response element and can reflect in vivo auxin levels [29]. Furthermore, we identified the insensitive phenotypes in response to $\mathrm{N}$ supplementation in the ospin $1 b$ mutant and discussed the relationship between the $\mathrm{N}$ stress response and the OsPIN1b-mediated ammonium assimilation signaling pathway. 


\section{Results}

2.1. Identification and Functional Assignment of Rice PIN Family Members in Various Tissues/Organs

Recently, Balzan (2014) first isolated 12 PIN-family genes in rice. However, biological information on the family members has not been particularly well described in rice. In the present study, we attempted to assign biological functions to the PIN genes in rice. To do this, we first carried out a comparative phylogenic analysis of 12 PIN genes from rice, 12 PIN genes from maize, and eight PIN genes from Arabidopsis. We identified eight subgroups (Figure S1); among them, four were shared with Arabidopsis, a model eudicot plant, two were monocot-specific subgroups and two were eudicot-specific subgroups. Therefore, we identified six subgroups in the rice PIN (OsPIN) family. Subgroups 1, 2, 3, and 4 were conserved in both dicots and monocots, whereas Subgroups 5 and 6 existed only in monocots. Subgroup 1 comprised four OsPIN genes (LOC_Os02g50960/OsPIN1b, LOC_Os06g12610/OsPIN1a, LOC_Os11g04190/OsPIN1c, and LOC_Os12g04000/OsPIN1d), whereas Subgroup 2 contained one OsPIN gene (LOC_Os06g44970/OsPIN2), Subgroup 3 contained three genes (LOC_Os01g69070/OsPIN5a, LOC_Os08g41720/OsPIN5b, and LOC_ Os09g32770/OsPIN5c), Subgroup 4 encompassed one gene (LOC_Os01g51780/OsPIN8), subgroup 5 comprised one gene (LOC_Os01g58860/OsPIN9), and Subgroup 6 had two genes (LOC_Os01g45550/OsPIN10a and LOC_Os05g50140/OsPIN10b). The detailed information of these findings is summarized in Table S1. Although the phylogenic analysis suggests the presence of functional similarity among the rice, maize, and Arabidopsis PIN gene products clustered in the same subgroup of the phylogenetic tree, it is not clear whether their biological functions are conserved between monocot and dicot plants. To identify the functional roles of OsPIN genes, we carried out a qRT-PCR analysis using leaf blade, leaf sheath, roots, mature flowers, mature seeds (seed), and young panicle tissues (Figure 1). OsPIN1a, OsPIN1b, OsPIN2, OsPIN9, and OsPIN10b exhibited the highest expression level in roots. In Subgroup 4, OsPIN5a was significantly expressed in leaf blades, and OsPIN5a and OsPIN5c showed a reproductive-tissue-preferred expression pattern. The expression patterns of OsPIN1c and OsPIN1d from PIN Subgroup 1 and OsPIN10a from Subgroup 6 suggested their roles in young panicle development; however, the overall expression of OsPIN8 was very low. The expression patterns of OsPIN genes determined by qRT-PCR suggest that they are useful indicators with respect to the functions of individual genes. 
(a)

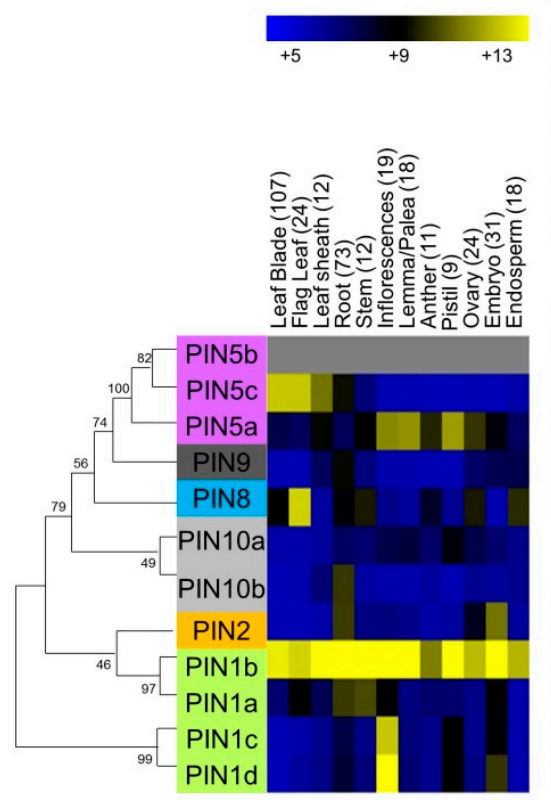

(b)

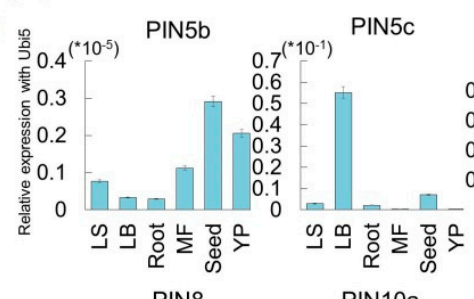

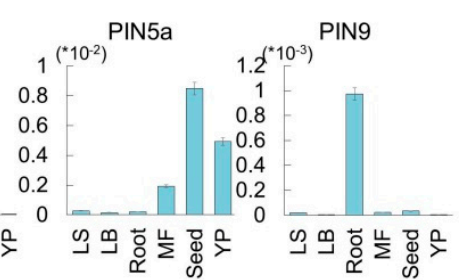

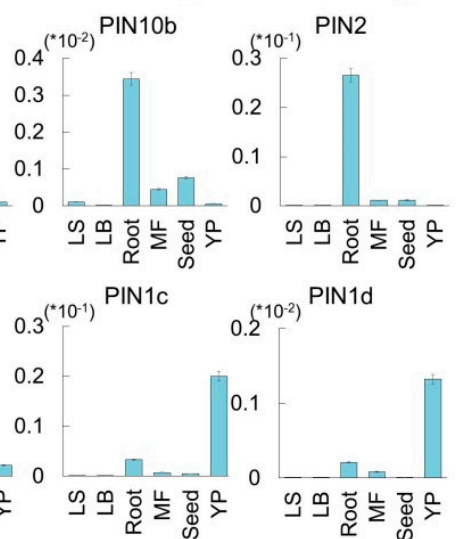

Figure 1. Heatmap expression analysis of OsPIN-family genes using meta-anatomical expression data, and validation of the expression patterns using qRT-PCR. (a) Affymetrix expression data consisting of eight tissues/organs were used to create the heatmap via the MeV software. Blue, low levels of expression; yellow, high levels of expression. (b) qRT-PCR was performed in six tissues/organs (leaf sheaths, leaf blades, roots, mature flowers, seeds, and young panicles). X-axis, tissues/organs used for qRT-PCR analysis; Y-axis, relative expression level to that of the rice ubiquitin 5 gene (OsUbi5, LOC_Os01g22490). All experiments were repeated three times using four biological replicates.

\subsection{Morphological Appearance of Rice Seedlings under Conditions of Nitrogen Depletion and Ammonium Supplementation}

To explore the responses of rice seedlings under conditions of $\mathrm{N}$ depletion and ammonium supplementation, pre-germinated seedlings were grown hydroponically for 14 days in distilled water, and further grown in N-deficient Yoshida solution $\left(0 \mathrm{mM}\left(\mathrm{NH}_{4}\right)_{2} \mathrm{SO}_{4}\right)$ for 3 days. Half of these plants were transferred to an $\mathrm{N}$-deficient solution, and the other half remained in the $\mathrm{N}$-sufficient $\left(0.5 \mathrm{mM}\left(\mathrm{NH}_{4}\right)_{2} \mathrm{SO}_{4}\right)$ solution for up to $48 \mathrm{~h}$. After completion of these treatments, we examined the changes in the morphological appearance of the seedlings and measured quantitative changes in all seedlings. For quantitative comparisons, the lengths of the roots and shoots were measured in all individual seedlings, and the mean value of each variable from 10 seedlings per treatment was determined from seedlings grown under both the $\mathrm{N}$-deficient and $\mathrm{N}$-supplemented conditions. Although there was no statistically significant difference, the root and shoot lengths under the Nsupplemented condition was slightly greater than those analyzed under the $\mathrm{N}$-deficient condition (Figure 2a,b). We examined changes in ammonium content, and it was confirmed that the ammonium content was significantly enhanced in both shoots and roots treated with ammonium for $48 \mathrm{~h}$ compared to those under $\mathrm{N}$-deficient conditions (Figure 2c). Our observations revealed that the $\mathrm{N}$ source was particularly important with respect to the stem and root growth of rice seedlings (Figure 2). 
(a)

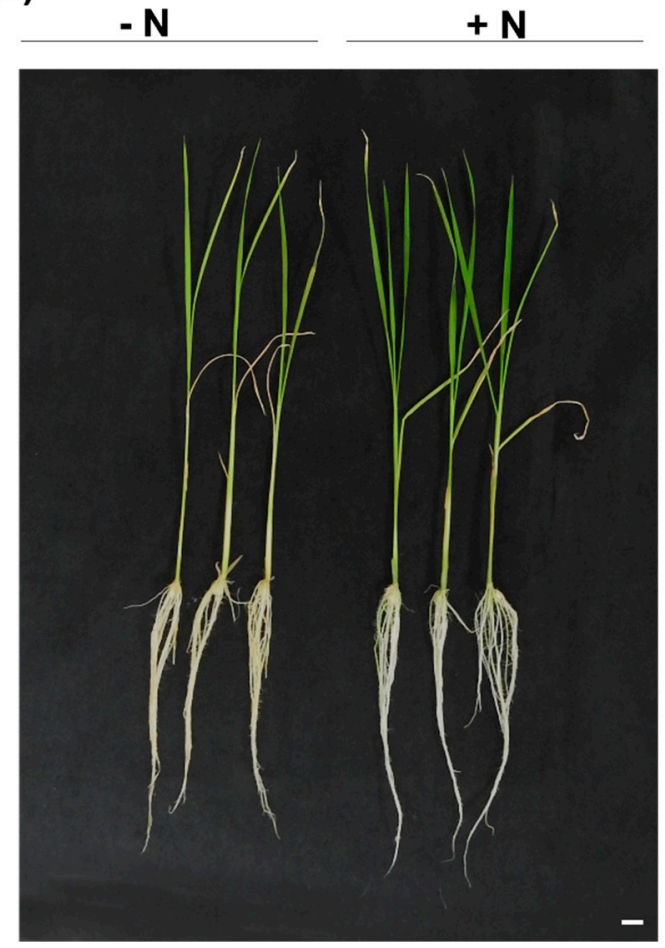

(b)

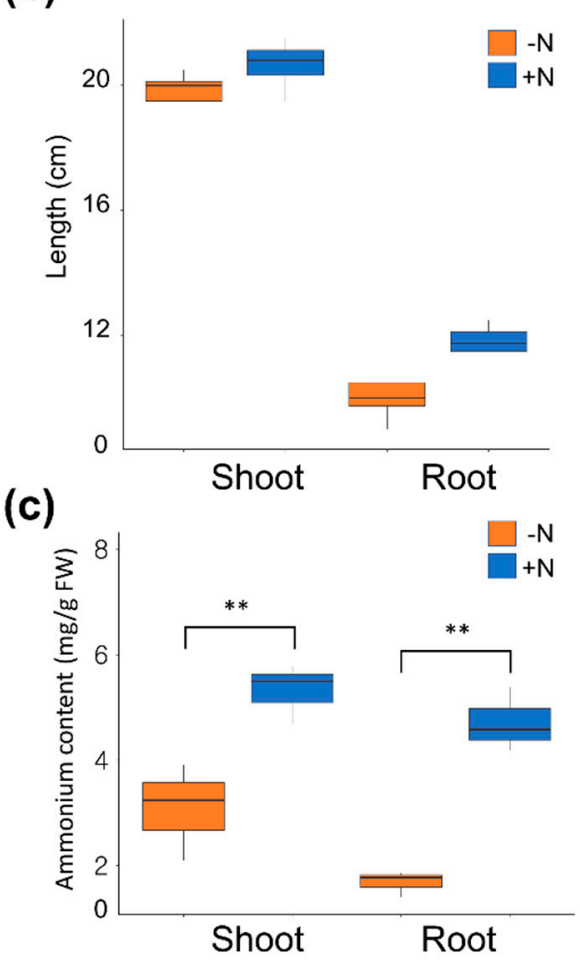

Figure 2. Morphological appearance, quantitative measurement for length, and ammonium measurement of the seedlings under different $\mathrm{N}$ conditions in rice. (a) Morphology of "Dongjin" seedlings. Pre-germinated seedlings were treated with an N-deficient solution for 3 days after growing for 14 days in distilled water. Subsequently, half of those seedlings were transferred to an $\mathrm{N}$-deficient solution, and the other half were transferred to an $\mathrm{N}$-sufficient solution for $48 \mathrm{~h}$. Comparison of the length (b) and the ammonium measurement (c) of roots and shoots under different $\mathrm{N}$ conditions (i.e., $-\mathrm{N}, \mathrm{N}$-deficient solution treated for $48 \mathrm{~h}$ with $0.5 \mathrm{mM}\left(\mathrm{NH}_{4}\right)_{2} \mathrm{SO}_{4} ;+\mathrm{N}$, N-sufficient solution treated for $\left.48 \mathrm{~h}\right)$. This experiment was repeated three times ( $n=7$ for each condition, with $n$ indicating independent experiments in each condition). ${ }^{* *}, p$-value $<0.01$, based on a $t$-test.

\subsection{OsPIN-Family Genes Are Closely Associated with Ammonium Treatment in Rice}

It has been shown that auxins play important roles in plant adaptation to $\mathrm{N}$ availability under climate change conditions [26]. To further test the relationship between the $\mathrm{N}$ response and OSPIN genes encoding auxin transporter in rice roots, we performed a time-course analysis of the gene expression patterns in response to $\mathrm{N}$ availability. The plants were grown in either water or $\mathrm{N}$-depleted hydroponic culture medium for 17 days. Half of the seedlings continued to be cultured under the same conditions, whereas the remaining seedlings were transferred to $\mathrm{N}$-sufficient medium and incubated for up to $7 \mathrm{~h}$. In total, three-time points were selected to test for short- and long-term responses to $\mathrm{N}$ deprivation and the effects of $\mathrm{N}$ supplementation on $\mathrm{N}$-starved plants. To evaluate the $\mathrm{N}$ response of the tested samples, we first checked the expression patterns of two marker genes for the nitrogen response, i.e., OsGS1;2 and OsNADH-GOGAT1 [23] (Figure 3) and found that peaks of expression of the two marker genes were observed at $3 \mathrm{~h}$ following $\mathrm{N}$ supplementation, after which their expression levels gradually decreased. The time course of the expression patterns of the OsPIN genes was then monitored under the same conditions. Our data showed that the expression of five OsPIN genes (OsPIN1a, OsPIN1b, OsPIN2, OsPIN9, and OsPIN10a) with root-preferred expression patterns was lower under the $\mathrm{N}$-sufficient condition than it was under the N-deficient condition. OsPIN1a and OsPIN9 were responsive to the $\mathrm{N}$ supplementation at all time points tested. However, OsPIN1b and OsPIN2 seemed to be involved in the early $\mathrm{N}$ response, whereas OsPIN10a appeared to function a little later in the roots under $\mathrm{N}$ supplementation. Interestingly, the expression of 
OsPIN5c, which exhibits a root-preferred expression pattern, was only higher under the $\mathrm{N}$-sufficient condition compared with the N-deficient condition. Although OsPIN5a, which exhibits a leaf-sheath-preferred expression pattern, was only weakly expressed in the roots, its expression was regulated by $\mathrm{N}$ supplementation at all time points tested. Therefore, OsPIN5a might play an important role in the transfer of auxins from the roots to the shoots under $\mathrm{N}$ supplementation. Taken together, these results indicate that the function of the PIN family genes is closely associated with the $\mathrm{N}$ response in rice.
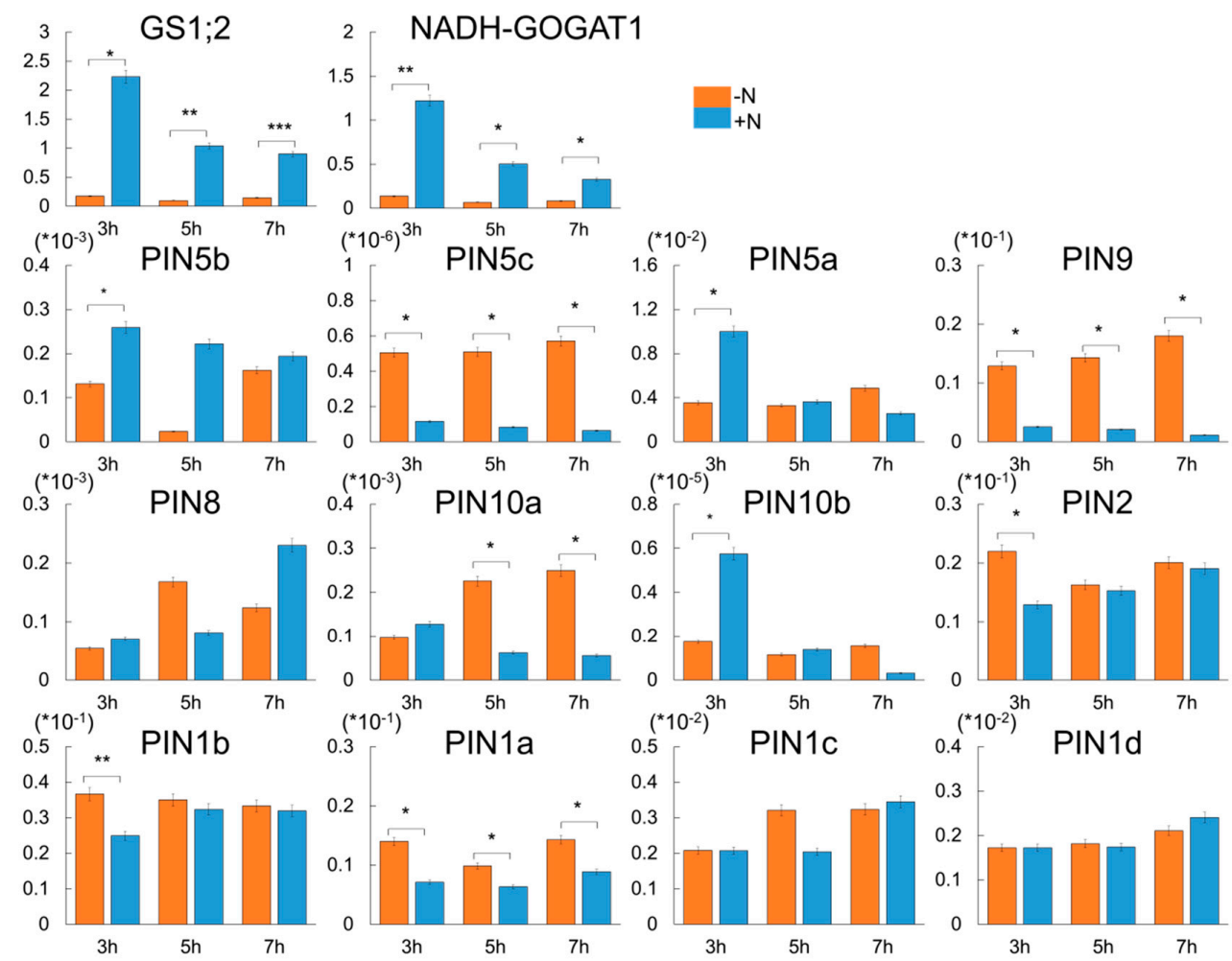

Figure 3. Expression analysis of 12 OsPIN-family genes in N-treated roots using qRT-PCR. Rice (Oryza sativa L. cv. Dongjin) seeds were grown in either water or $\mathrm{N}$-depleted hydroponic culture medium for 17 days. Half of the seedlings continued to be cultured under the same condition, whereas the remaining seedlings were transferred to $\mathrm{N}$-sufficient medium $(0.5 \mathrm{mM}$ $\left.\left(\mathrm{NH}_{4}\right)_{2} \mathrm{SO}_{4}\right)$ and incubated for up to $7 \mathrm{~h}$. X-axis, sampling time used for qPCR analysis; Y-axis, relative expression level to that of OsUbi5. ${ }^{* * *}, p$-value $<0.001,{ }^{* *}, p$-value $<0.01,{ }^{*}, p$-value $<0.05$, based on a $t$-test.

\subsection{Ammonium Resupply Decreases Auxin Response in Root Tips and Lateral Roots via the DR5::VENUS System}

Auxins might be involved in the regulation of root development in response to $\mathrm{N}$ supply. To investigate the interaction between auxin accumulation and root architecture changes for the duration of the N supply, we used the DR5::VENUS reporter line, which shows a highly active synthetic auxin response and, thus, can reflect in vivo auxin levels [29]. The DR5::VENUS reporter line was transferred to an $\mathrm{N}$-deficient solution $(0 \mathrm{mM} \mathrm{N})$ for 3 days after incubation of pre-germinated seedlings for 14 days in a hydroponic culture medium with distilled water. These conditions represented 17 days of $\mathrm{N}$-deprivation treatment. Half of these plants were incubated in an ammonium-supplemented solution $\left(0.5 \mathrm{mM}\left(\mathrm{NH}_{4}\right)_{2} \mathrm{SO}_{4}\right)$ for up to $48 \mathrm{~h}$. Compared with the N-deficient condition $(0 \mathrm{mM}$ $\left.\left(\mathrm{NH}_{4}\right)_{2} \mathrm{SO}_{4}\right)$, we confirmed that ammonium supplementation for $48 \mathrm{~h}$ decreased the DR5VENUS signal in the root tips and in the lateral root initiation zone (Figure 4). These results were consistent with the decreased expression pattern of the OsPIN-family genes in the presence of an ammonium-dependent response following $\mathrm{N}$ deficiency (Figure 3). 


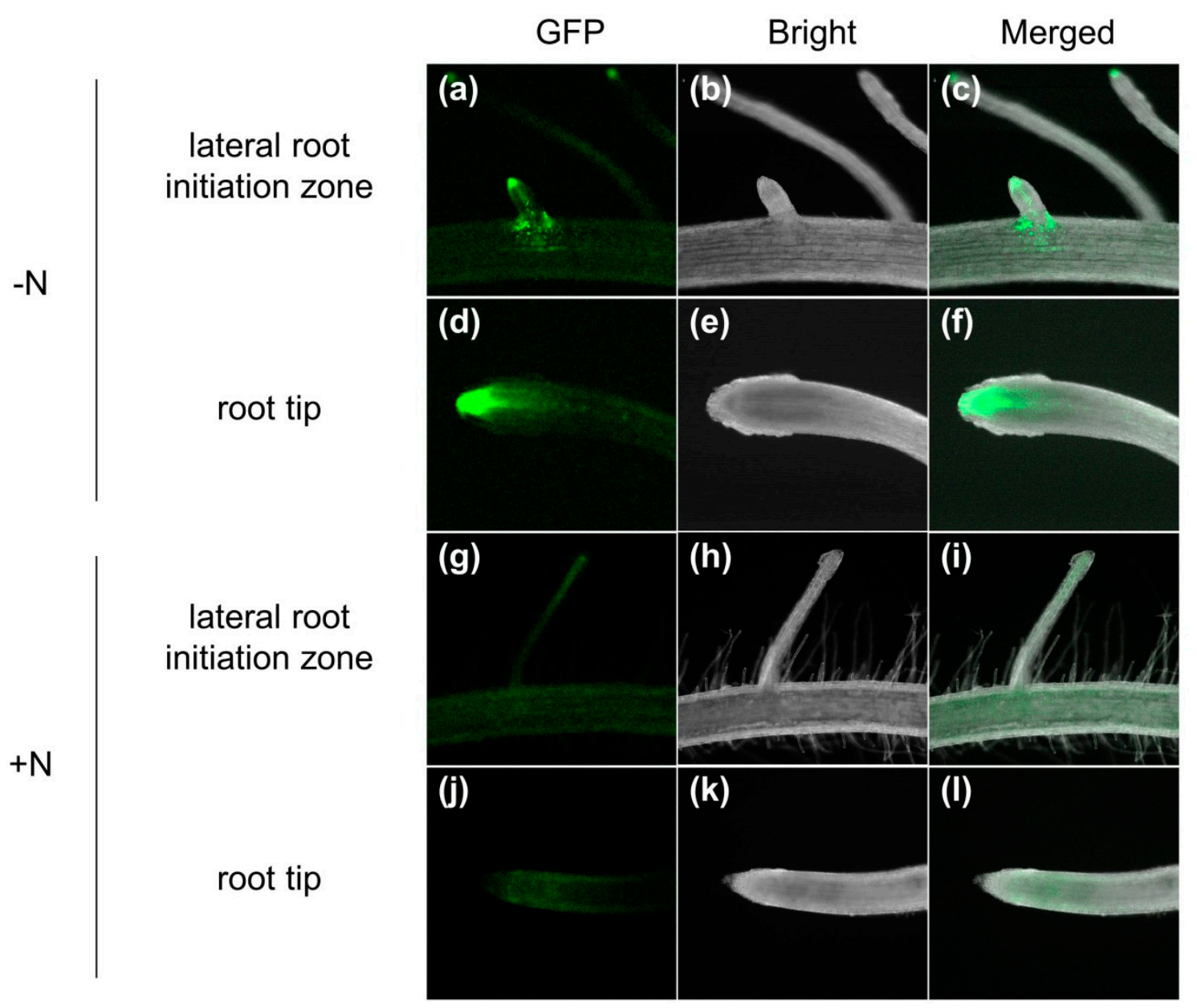

Figure 4. Confocal images of DR5 GFP expression in rice roots. Pre-germinated seedlings were treated with an N-deficient solution $\left(0\left(\mathrm{NH}_{4}\right)_{2} \mathrm{SO}_{4}\right)$ for 3 days after growing for 14 days in distilled water. Subsequently, half of those seedlings were transferred to an $\mathrm{N}$-deficient solution, and the other half were transferred to an $\mathrm{N}$-sufficient solution. Lateral root initiation zone, under $\mathrm{N}$-deficient solution and $\mathrm{N}$-sufficient solution $\left(0.5 \mathrm{mM}\left(\mathrm{NH}_{4}\right)_{2} \mathrm{SO}_{4}\right)(\mathbf{a}-\mathbf{f})$; root tip, under $\mathrm{N}$-deficient solution and $\mathrm{N}$-sufficient solution $(\mathbf{g}-\mathbf{l})$. $-\mathrm{N}$, roots treated with the $\mathrm{N}$-deficient solution $(\mathbf{a}-\mathbf{c}, \mathbf{g}-\mathbf{i}) ;+\mathrm{N}$, roots treated with the $\mathrm{N}$-sufficient solution $(\mathbf{d}-\mathbf{f}, \mathbf{j}-\mathbf{l})$ for $48 \mathrm{~h}$.

2.5. The Ospin1b Mutant (3A-04335) Displayed No Response to Ammonium Supplementation after Long-Term N Deficiency

To analyze the functional significance of OsPIN-family genes in response to ammonium supply after long-term $\mathrm{N}$ deficiency, we used an ospin $1 b$ mutant that has been reported previously [27]. We grew ospin $1 b$ and WT plants for 10 days after germination on Murashige and Skoog (MS) media, and the seedlings were incubated hydroponically for 14 days in distilled water and further grown in N-deficient Yoshida solution $\left(0 \mathrm{mM}\left(\mathrm{NH}_{4}\right)_{2} \mathrm{SO}_{4}\right)$ for 3 days. We confirmed that the ospin $1 b$ mutant has a shorter root phenotype compared with the WT plants, as reported previously (Figure 5a). Half of these plants were transferred to an $\mathrm{N}$-deficient solution, and the remaining plants were transferred to an $\mathrm{N}$-sufficient solution $\left(0.5 \mathrm{mM}\left(\mathrm{NH}_{4}\right)_{2} \mathrm{SO}_{4}\right)$. After exposure to the $\mathrm{N}$-sufficient hydroponic medium for $48 \mathrm{~h}$, the root and shoot lengths and weight of the WT under N-supplemented conditions were increased significantly more than those analyzed under $\mathrm{N}$-deficient conditions, whereas the ospin $1 b$ mutant exhibited an insensitive phenotype in response to $\mathrm{N}$-supplementation (Figure 5a-c). We also measured the leaf color and chlorophyll content between the WT and ospin $1 b$ mutants under $\mathrm{N}$-supplementation and $\mathrm{N}$-deficiency conditions. We then identified that the chlorophyll content of the WT was increased when nitrogen was resupplied after long-term $\mathrm{N}$-starvation, but the $\mathrm{N}$-supplementation effect did not occur significantly in 
the ospin $1 b$ mutant (Figure $5 \mathrm{~d}, \mathrm{e}$ ). In addition, we found that there was no significant difference in the ammonium content of the ospin $1 b$ mutants between $\mathrm{N}$-supplementation and $\mathrm{N}$-deficiency conditions (Figure 6). These results indicate that the ospin $1 b$ mutant is insensitive to $\mathrm{N}$-supplementation after long-term $\mathrm{N}$-starvation.
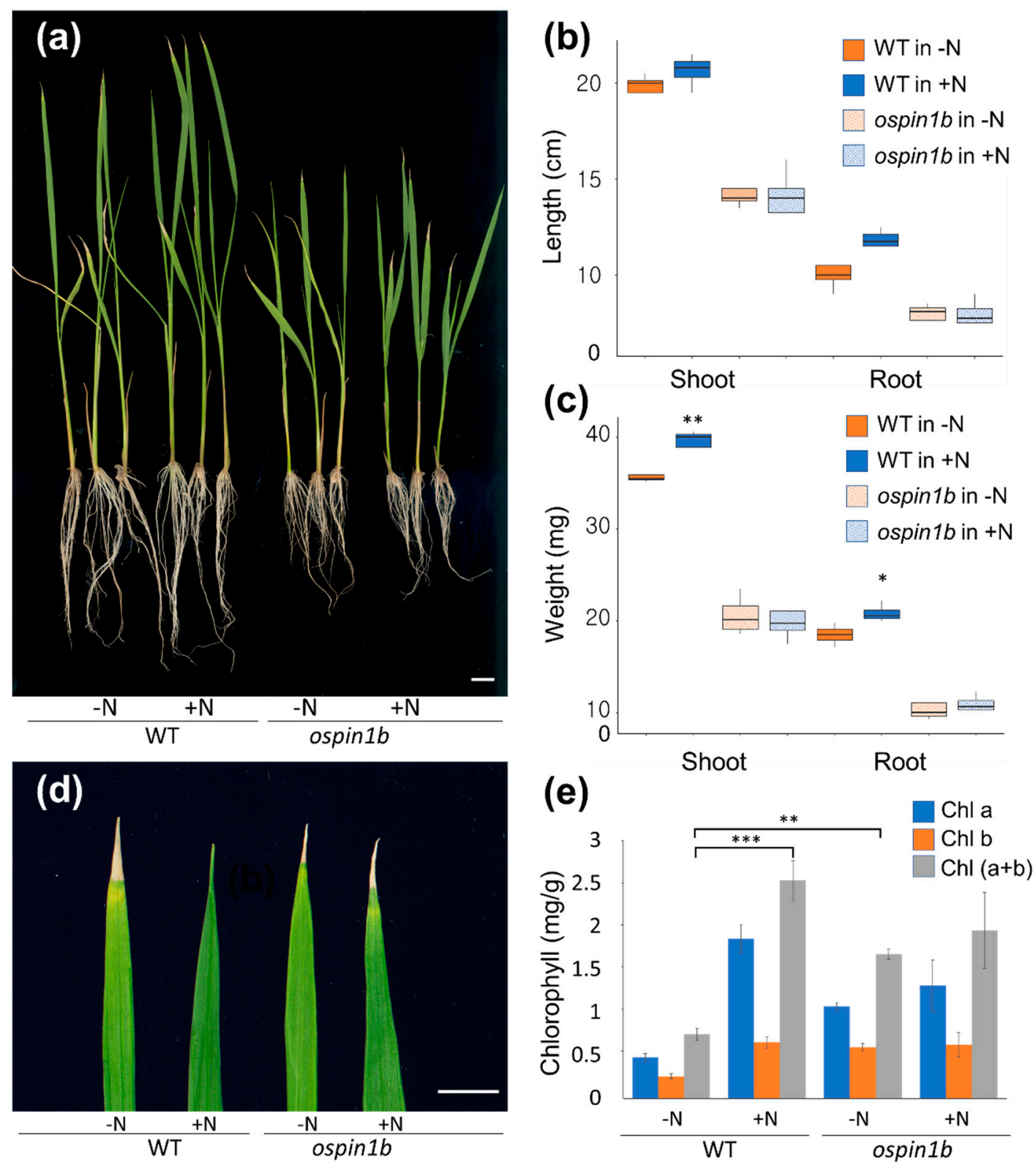

Figure 5. Morphological appearance, quantitative measurement for length and weight, and chlorophyll content measurement of the seedlings between WT and ospin1b plants under different N conditions. (a) Morphology of WT and ospin1b plants at the seedling stage in response to ammonium supplementation after long-term N-deficiency. Pre-germinated seedlings were treated with an N-deficient solution (0 mM (NH4)2SO4) for 3 days after growing for 14 days in distilled water. Subsequently, half of these seedlings were transferred to an N-deficient solution, and the other half were transferred to an N-sufficient solution (0.5 mM (NH4)2SO4). Comparison of the length (b) and dry weight (c) of roots and shoots between WT and ospin1b plants under different $\mathrm{N}$ solutions $(-\mathrm{N}, \mathrm{N}$-deficient solution; +N, N-sufficient solution) for $48 \mathrm{~h}$. Comparison of the leaf color (d) and chlorophyll (e) of shoots between WT and ospin1b plants under different $\mathrm{N}$ solutions $(-\mathrm{N}, \mathrm{N}$-deficient solution; $+\mathrm{N}$, N-sufficient solution). Nitrogen was treated for $48 \mathrm{~h}$. This experiment was repeated three times ( $n=7$ for each condition in WT and ospin1b plants). ${ }^{* *}, p$-value $<0.001,{ }^{* *}, p$-value $<0.01,{ }^{*}, p$-value $<0.05$, based on a $t$-test. 
(a)

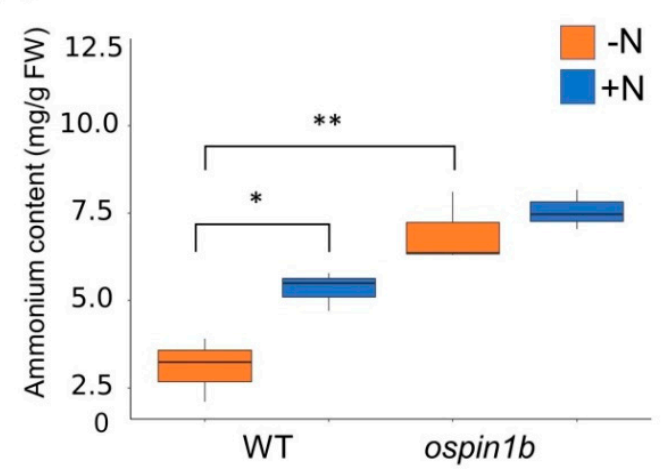

(b)

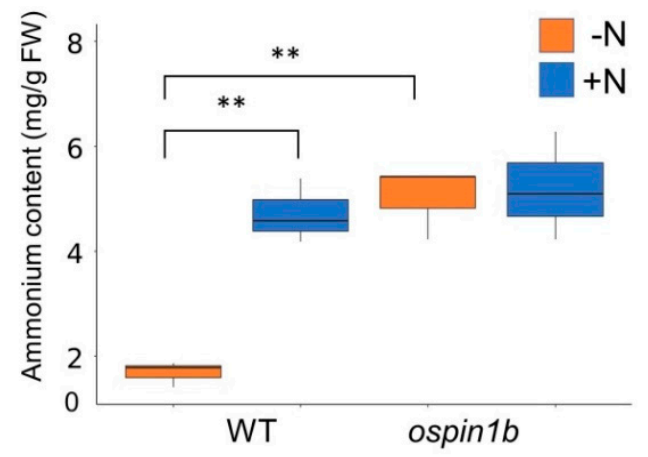

Figure 6. Ammonium content measurement of the seedlings between WT and ospin $1 b$ plants under different N-conditions. (a) The Ammonium content measurement between WT and ospin $1 b$ of shoot (a) and root (b) of seedlings between WT and ospin $1 b$ plants under different N-conditions. Pre-germinated seedlings were treated with a N-deficient solution $(0 \mathrm{mM}$ $\left.\left(\mathrm{NH}_{4}\right)_{2} \mathrm{SO}_{4}\right)$ for 3 days after growing for 14 days in distilled water. Subsequently, half of these seedlings were transferred to an N-deficient solution, and the other half were transferred to an $\mathrm{N}$-sufficient solution $\left(0.5 \mathrm{mM}\left(\mathrm{NH}_{4}\right)_{2} \mathrm{SO}_{4}\right)(-\mathrm{N}, \mathrm{N}$-deficient solution; $+\mathrm{N}$, N-sufficient solution). Nitrogen was treated for $48 \mathrm{~h}$. This experiment was repeated three times $(n=7$ for each condition in WT and ospin1b plants). ${ }^{* *}, p$-value $<0.01,{ }^{*}, p$-value $<0.05$, based on a $t$-test.

\subsection{Mutation of OsPIN1b Alters the Expression Pattern of Ammonium-Response-Related Genes}

To investigate the effect of a mutation in the OsPIN1b gene on the expression of genes involved in the N-signaling pathway, qRT-PCR was carried out using root samples of WT and ospin $1 b$ plants grown under N-deprivation conditions $\left(0 \mathrm{mM}\left(\mathrm{NH}_{4}\right)_{2} \mathrm{SO}_{4}\right)$ for 17 days and $3 \mathrm{~h}$, or in $\mathrm{N}$-supplemented medium $\left(0.5 \mathrm{mM}\left(\mathrm{NH}_{4}\right)_{2} \mathrm{SO}_{4}\right)$ for $3 \mathrm{~h}$, after $\mathrm{N}$-deprivation conditions for 17 days. To further determine how the ospin $1 b$ mutation altered the root development mediated by ammonium-dependent response genes and root-growth-related genes, we analyzed the expression pattern of OsAMT1;1-3, OsGS1;2, OsNADH-GOGAT1, OsGDH2, OsAS2, and OsGLU3 as the ammonium-dependent response genes [23,30,31] (Figure 7). As expected, five genes (OsAMT1;1, OsAMT1;2, OsGS1;2, OsNADH-GOGAT1, and OsGDH2) were upregulated and two genes (OsAMT1;3 and OsAS2) were downregulated when placed under the $\mathrm{N}$-supplementation condition for $3 \mathrm{~h}$ after long-term N-deprivation treatment in WT plants. Interestingly, although the expression of OsAMT1;2 and OsGDH2 was increased by ammonium supplementation following $\mathrm{N}$ deficiency, their expression change was significantly decreased in the ospin $1 b$ mutant compared with the WT plants. The expression of OsNADH-GOGAT1 under ammonium supply following $\mathrm{N}$ deficiency was increased in the ospin $1 b$ mutant compared with the WT plants. However, the expression of OsGS1;2, OsAMT1;1, OsAMT1;3, and OsAS2 was not significantly different between the ospin $1 b$ mutant and WT plants. Taken together, our results suggest that $O s A M T 1 ; 2$ and $O s G D H 2$ are responsible for the ammonium-dependent response in the ospin $1 b$ mutant.

In the case of OsGLU3, which is related to root development and functions in the synthesis of cellulose when nitrogen is deficient, its expression was decreased when ammonium was administered under nitrogen-deficient conditions for a long period of time in WT plants. In the ospin $1 b$ mutant, the expression of OsGLU3 not only dramatically decreased in the $\mathrm{N}$-deprivation condition, but also significantly reduced when ammonium was supplied (Figure 7). This result indicates that OsGLU3 is regulated by OsPIN1b, regardless of $\mathrm{N}$ depletion or $\mathrm{N}$ supplementation. 


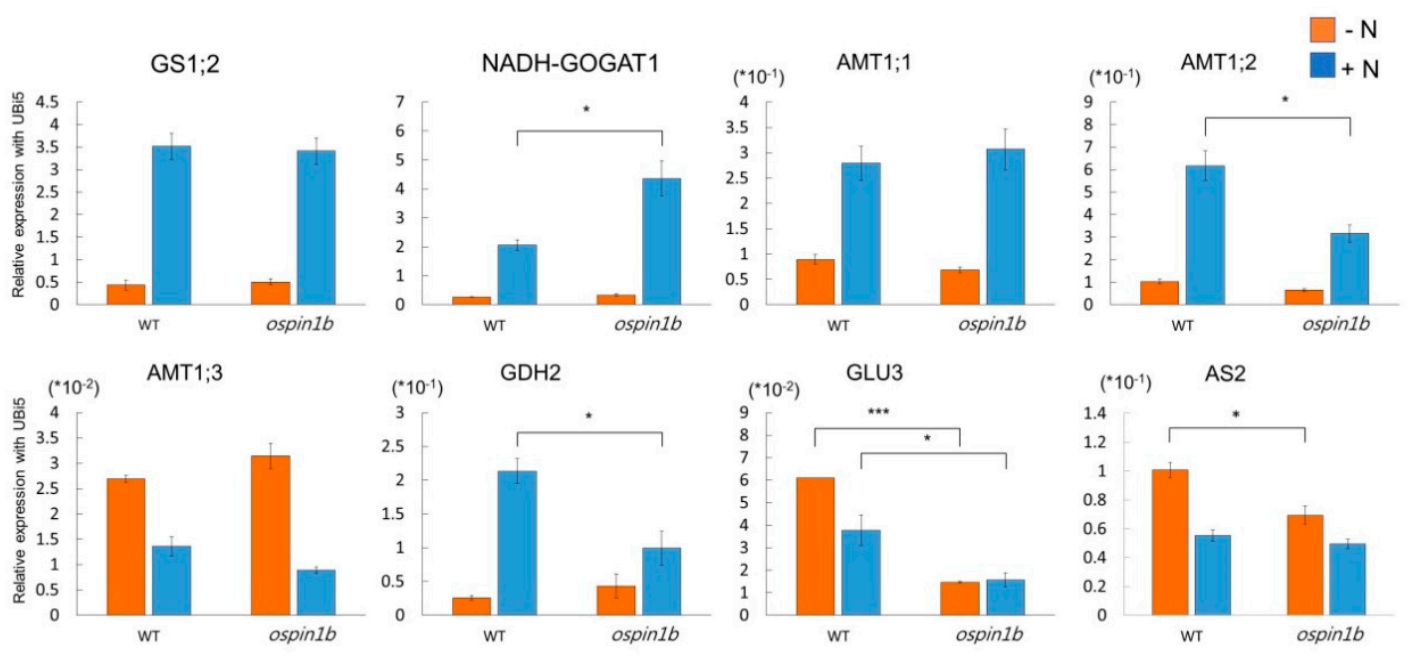

Figure 7. Expression patterns of ammonium-responsive genes between ospin $1 b$ and WT plants under different $\mathrm{N}$-conditions. The data show the expression patterns of $\mathrm{N}$-assimilation-pathway genes between ospin $1 b$ and WT plants under different N-conditions using qRT-PCR. The relative expression level to that of the rice ubiquitin 5 gene (OsUbi5, LOC_Os01g22490) was used for the expression analysis. All experiments were repeated using three biological replicates and each replicate was pooled with 5 samples. ${ }^{* * *}, p$-value $<0.001,{ }^{*}, p$-value $<0.05$, based on a $t$-test.

\section{Discussion}

\subsection{Roles of PIN-Family Genes in Rice}

Although auxin plays an essential role in regulating both plant growth and tolerance to abiotic stresses, research on the relationship between nitrogen utilization efficiency and auxins is very limited. In this study, we first tried to identify the functional roles of the PIN (auxin efflux carrier) family of genes in rice, through a qRT-PCR analysis in various organs/tissues and in the presence of the ammonium-dependent response. Rice carries 12 PIN family members, and a phylogenetic analysis classified these members into six subgroups [32]. Our results indicated that Subgroups 1, 2, 3, and 4 were auxin efflux carriers that existed in both dicots and monocots, whereas Subgroups 5 and 6 were auxin efflux carriers that existed only in monocots. As indicated, OsPIN10 $a$ and OsPIN10b of Subgroup 6 and OsPIN9 of Subgroup 5 might be monocot specific, as they are also conserved in maize and rice (Figure S1) [10,33]. It has been shown that AtPIN1 is essential for the initiation and development of lateral root primordia in Arabidopsis [34]. Unlike AtPIN1, which functions as the sole PIN-family member in the Arabidopsis genome, the rice PIN1 family contains four homologs, namely, OsPIN1a, 1b, 1c, and 1d. Wang et al., (2004) tried to identify the functional roles of OsPIN genes through a spatial/temporal expression analysis and organization of the protein structures, and confirmed that expression of all OsPIN genes, except OsPIN2 and OsPIN9, was enhanced following treatment with $10 \mu \mathrm{M}$ indole-3-acetic acid (IAA) for 7 days. Among the nine OsPIN genes, OsPIN1 $a$ and OsPIN1b are only induced by IAA, and OsPIN1b of them is expressed in the root cap where the distal auxin maximum is created [35]. Recently, it has been shown that OsPIN1b is involved in seminal root elongation by regulating root apical meristem activity under lownutrient conditions. It was also confirmed that the $\left[{ }^{3} \mathrm{H}\right] \mathrm{IAA}$ transport activity and auxin concentration decreased significantly at the root tip of the ospin $1 b$ knockout mutant [27]. Moreover, we confirmed that the ospin $1 b$ mutant displayed markedly shorter roots and a lower number of crown roots (Figure 5). These results indicate that OsPIN1b is an auxin transporter that regulates the development of the roots in both normal and nutrient-limited conditions [35,36] (Figures 1 and 5). 


\subsection{Auxin Is Involved in the Ammonium-Dependent Response Mediated by Rice PIN-Family Genes Encoding Auxin Efflux Carriers}

Ammonium is the major source of inorganic nitrogen for plants. Ammonium promotes plant growth at low external supplies, while high ammonium supplies cause toxicity in plants. Recently, auxins have been shown to play important roles in plant adaptation to the fluctuating availability of usable nitrogen [26]. In Arabidopsis, the auxinresistant mutants aux1, axr1, and axr2 were shown to be insensitive to $\mathrm{NH}_{4}{ }^{+}$-mediated root growth inhibition [37], and shoot-supplied $\mathrm{NH}_{4}{ }^{+}$inhibited lateral root emergence by interfering with AUX1, an auxin influx transporter, from shoots to roots [38]. In addition, $\mathrm{NH}_{4}{ }^{+}$treatment altered the expression levels of several auxin signaling genes (OsIAA24 (LOC_Os07g08460), OsIAA19 (LOC_Os05g48590), OsGH3-13 (LOC_Os11g32510), and OsIAA10 (LOC_Os02g57250)) and auxin transporters (OsPIN5a, OsPIN5b, and OsPIN5C) and delayed the rice root tip response to gravity changes [39]. These findings suggest that auxin is tightly associated with $\mathrm{NH}_{4}{ }^{+}$-mediated root growth. Conversely, the molecular mechanism of auxin and $\mathrm{NH}_{4}{ }^{+}$interaction remains elusive in rice. Our results also indicate that PIN expression is repressed by $\mathrm{NH}_{4}{ }^{+}$supply in rice roots, and that the auxin response is decreased in the rice root tips and in the lateral root initiation zone under the ammoniumdependent response following $\mathrm{N}$ deficiency, as assessed using DR5-VENUS lines (Figure 4). The five OsPIN genes that are localized to the plasma membrane and exhibit root-preferred expression patterns [40,41], i.e., OsPIN1a, OsPIN1b, OsPIN2, OsPIN9, and OsPIN10a, were negatively regulated by the $\mathrm{NH}_{4}{ }^{+}$-dependent response (Figure 3). Conversely, OsPIN5s, which has been reported to localize to the endoplasmic reticulum, showed a different pattern among the three members [10] (Figure 1). OsPIN5c, which is highly expressed in leaf blades, responded negatively to the $\mathrm{NH}_{4}{ }^{+}$-dependent response, whereas OsPIN5a and OsPIN5b, which are highly expressed in seeds and flowers, responded positively to the $\mathrm{NH}_{4}{ }^{+}$-dependent response (Figure 3).

Root gravitropism is affected by many environmental stresses including salinity, drought, and nutritional deficiencies [42-44]. Recently, it was reported that excessive ammonium $\left(\mathrm{NH}_{4}{ }^{+}\right)$not only inhibits root elongation and lateral root formation, but also accompanies the loss of root gravitropism in Arabidopsis. Zou et al. (2012) showed that excessive $\mathrm{NH}_{4}{ }^{+}$treatment significantly decreased the expression of the $\beta$-glucuronidase (GUS) signal of DR5::GUS as the auxin-responsible reporter in root tip cells [45]. Our results also show that the DR5::VENUS signal and the expression levels of most of the PIN genes were reduced when ammonium was given after a prolonged period of nitrogen deficiency (Figures 3 and 4). AtPIN2, that is predominantly found with apical polarity in the root epidermis and lateral root cap and basal polarity in the cortex, is a major component for basipetal auxin transport, with an involvement in root gravitropism [46-48]. Although we did not observe a change in root gravity during $\mathrm{NH}_{4}{ }^{+}$treatment, it was confirmed that the expression of the OsPIN2 gene, in addition to the homology of AtPIN2-which was previously known to be involved in root gravitropism-decreased during $\mathrm{NH}_{4}{ }^{+}$treatment after long-term $\mathrm{N}$ deficiency (Figure 3). This suggests that OsPIN2 might be involved in root gravitropism under the $\mathrm{NH}_{4}{ }^{+}$response.

In addition, we identified the phenotype of the ospin $1 b$ mutant after treatment with ammonium following long-term $\mathrm{N}$ deprivation. The biomass and ammonium contents of the roots and shoots were increased in WT plants in response to ammonium supplementation after long-term $\mathrm{N}$ deprivation, whereas no response was observed in the ospin $1 b$ mutant under the same conditions (Figures 5 and 6). Ammonium nutrition is known to affect chlorophyll content in rice [49]. Our results were consistent with the fact that the WT increased the total chlorophyll content when ammonium was supplied after prolonged depletion of all nitrogen sources, whereas the mutants did not differ in chlorophyll content (Figure 5d,e). Low auxin levels are known to increase sugar levels, thereby inhibiting the expression of photosynthetic genes and the production of chlorophyll [50]. Moreover, it has been reported that the leaves of the OsPIN5-overexpressing transgenic plant have increase chlorophyll levels [10]. Our results also suggest that nitrogen supply increases chlorophyll 
production, while low auxin levels inhibit chlorophyll production. Therefore, these results reveal that OsPIN1b might be involved in the growth of rice plants due to its association with the ammonium response after long-term $\mathrm{N}$ deprivation.

\subsection{OsPIN1b Is Involved in Ammonium Assimilation}

The ospin $1 b$ mutant displayed suppressed root development compared with the WT plants as a consequence of the ammonium response after long-term $\mathrm{N}$ deprivation. To examine whether the mutation of the OsPIN1b gene is involved in the $\mathrm{N}$-signaling pathway, the expression of the $\mathrm{N}$-signaling pathway-related genes was analyzed in the ospin $1 b$ mutant. Two ammonium-assimilation-related genes (OsAMT1;2 and OsGDH2) were significantly altered in ospin $1 b$. Ammonium assimilation is an important process of the ammonium-induced physiological response in plants. It has been suggested that the ammonium-use efficiency of plants is related to their ability to assimilate ammonium. Once ammonium has entered plant cells via the ammonium transporter 1 (AMT1) [15,17], the ammonium is rapidly assimilated into glutamine and glutamate through the glutamine synthase/glutamate synthase (GS-GOGAT) cycle [51]. In addition to the GS-GOGAT cycle, an alternative pathway of ammonium assimilation is driven by the NADH-dependent glutamate dehydrogenase (GDH), which synthesizes glutamate in the cytoplasm using ammonium and 2-oxoglutarate and is upregulated by the supply of ammonium [52]. Rice INDETERMINATE DOMAIN 10 (OsIDD10), a $\mathrm{NH}_{4}{ }^{+}$signaling transcription factor, was reported to regulate the expression of $\mathrm{NH}_{4}{ }^{+}$uptake and $\mathrm{N}$-assimilation genes [39]. Osidd10 mutants exhibited an ammonium-hypersensitive root growth defect [53]. Furthermore, among the ammonium uptake and assimilation genes, OsAMT1;2 and OsGDH2 were shown to be significantly dependent on the regulation of OsIDD10 expression for ammonium-mediated induction processes [53]. The expression levels of both OsAMT1;2 and $O s G D H 2$ were significantly lower in the ospin $1 b$ mutant compared with WT plants for the ammonium response after long-term $\mathrm{N}$ deprivation (Figure 7). This suggests that OsAMT1;2 and OsGDH2 in the ammonium assimilation pathway can be regulated by OsPIN1b. However, the clear result of mutual regulation needs to be confirmed in future studies. OsGLU3, which encodes a beta-1,4-endoglucanase, affects cellulose synthesis for root elongation in rice [31]. Osglu3-1 has been reported to have a reduced content of crystalline cellulose in its root cell walls, a shorter root cell length, and a slightly smaller root meristem [54]. Interestingly, OsGLU3 expression was dramatically reduced in the ospin $1 b$ mutant (Figure 7), and a shorter root length was observed in the ospin $1 b$ mutant compared with WT plants, implying that OsPIN1b might be involved in the root cell elongation by positively regulating the expression of OsGLU3. Based on the current study and previous studies, we propose a simple model to explain the relationship between OsPIN1b and N-assimilation in rice under the $\mathrm{NH}_{4}{ }^{+}$-dependent response (Figure 8). Taken together, our findings provide molecular and physiological evidence that the PIN family is involved in the ammonium assimilation process of rice, which is a model crop. This study is intended to be helpful for future research pertaining to the improvement of the nitrogen use efficiency associated with OsPIN1b. 


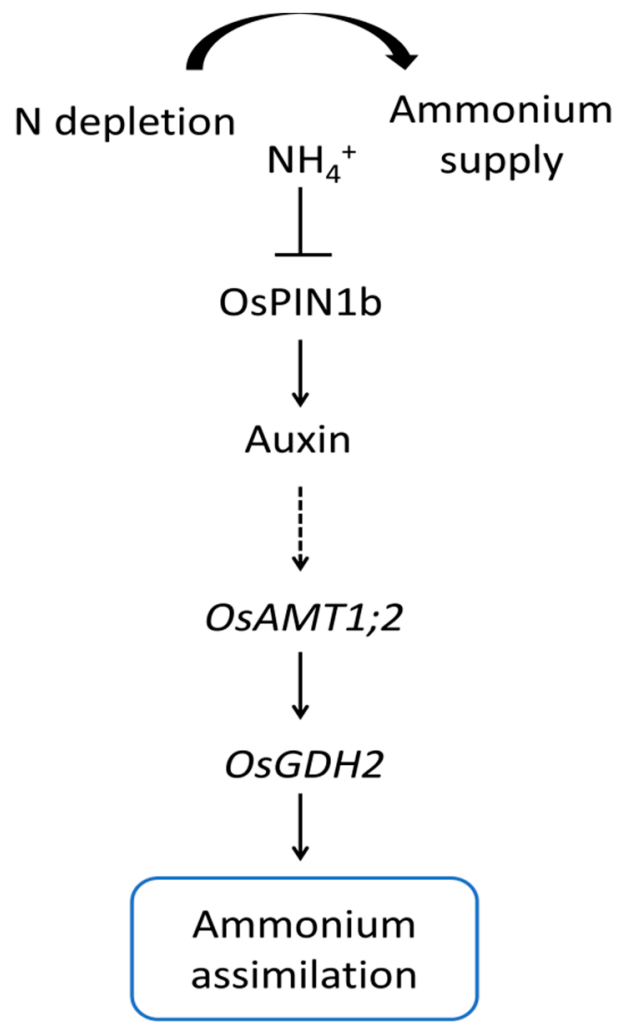

Figure 8. Working model of the function of OsPIN1b associated with N-assimilation-pathway genes in rice. Arrows $=$ a positive regulatory action; lines ending in a flat line = a negative regulatory action; dotted line $=$ expected regulatory action.

\section{Conclusions}

In summary, by qRT-PCR analysis of OsPINs and the expression analysis of the DR5::VENUS reporter line, we have shown that ammonium supply after long-term $\mathrm{N}$ starvation could lead to reduced auxin distribution. Furthermore, the ospin $1 b$ mutant showed an insensitive phenotype under the ammonium-dependent response after longterm $\mathrm{N}$ deficiency and regulated several genes in the $\mathrm{N}$-assimilation pathway. These molecular and physiological findings suggest that auxin is involved in the ammonium assimilation process of rice. We expect that this study will be helpful in improving nitrogen use efficiency in crop plants, acting as a basis for future studies.

\section{Materials and Methods}

\subsection{Multiple Sequence Alignment and Phylogenetic Analysis}

To perform a phylogenomic analysis of PIN-family proteins in rice, Arabidopsis, and maize, we collected 12 family members from the Rice Genome Annotation Project (http: / / rice.plantbiology.msu.edu/accessed on 15 February 2021), as well as 8 Arabidopsis and 11 maize family members from GreenPhyl v5 (http:/ / www.greenphyl.org/cgi-bin/index. cgi accessed on 15 February 2021) (Table S1). The phylogenetic analysis used MEGA7 under the following parameters: neighbor joining, complete deletion, and bootstrap with 500 replicates (Figure S1), as described previously $[55,56]$. We also generated a phylogenic tree for rice PINs, to integrate meta-expression data from data from 983 Affymetrix arrays (Figure 1). The multiple sequence alignment of these proteins was conducted using the ClustalX program [57].

\subsection{Meta-Analysis of Organ-Specific Expression Profiles}

The integration of transcriptomes into a phylogenetic context can drive more effective experimental strategies for further functional analysis [58]. Therefore, we used a meta- 
analysis of the expression profiles of OsPIN-family genes in six tissues/organs based on the data from 983 Affymetrix arrays, downloaded from the NCBI gene expression omnibus (GEO, http:/ / www.ncbi.nlm.nih.gov/geo/ accessed on 15 February 2021) [28]. We then uploaded the $\log _{2}$ normalized intensity data in tab-delimited text format into the Multi Experiment Viewer (MEV, http:/ / mev.tm4.org/\#/welcome accessed on 15 February 2021) and illustrated these data using heat maps (Figure 1).

\subsection{Plant Material and Stress Treatment}

Rice (Oryza sativa L. cv. Dongjin) seeds were germinated on MS medium under controlled conditions of $28^{\circ} \mathrm{C}$ day $/ 25^{\circ} \mathrm{C}$ night temperatures, $8 \mathrm{~h}$ light $/ 16 \mathrm{~h}$ dark cycle, and $78 \%$ relative humidity, after sterilization with $50 \%(w / v)$ commercial bleach for 30 min with gentle shaking, as described previously $[59,60]$. For the anatomical expression analysis, roots, leaf sheaths, leaf blades, panicles before heading, flowers at the heading stage, and seeds at 10 and 15 days after pollination were harvested to extract total RNA. For the ammonium response analysis in rice after long-term $\mathrm{N}$ starvation, we used rice $c v$. Dongjin, and the DR5-GFP-expressing line and the T-DNA insertional mutant of the OsPIN1b gene (3A-04335) were germinated on MS medium at $28{ }^{\circ} \mathrm{C}$ for 10 days. The seedlings were incubated hydroponically for 14 days in distilled water and further grown in $\mathrm{N}$-deficient Yoshida solution $\left(0 \mathrm{mM}\left(\mathrm{NH}_{4}\right)_{2} \mathrm{SO}_{4}\right)$ for 3 days. Half of these plants were transferred to an $\mathrm{N}$-deficient solution, and the remaining plants were transferred to an $\mathrm{N}$-sufficient solution $\left(0.5 \mathrm{mM}\left(\mathrm{NH}_{4}\right)_{2} \mathrm{SO}_{4}\right)$. The Yoshida medium consisted of $0.3 \mathrm{mM} \mathrm{NaH} \mathrm{PO}_{4}, 0.5 \mathrm{mM} \mathrm{K}_{2} \mathrm{SO}_{4}$, $1.0 \mathrm{mM} \mathrm{CaCl}_{2}, 1.6 \mathrm{mM} \mathrm{MgSO}_{4}, 0.17 \mathrm{mM} \mathrm{NaSiO}_{3}, 50 \mu \mathrm{m}$ Fe-EDTA, $0.06 \mu \mathrm{M}\left(\mathrm{NH}_{4}\right)_{6} \mathrm{Mo}_{7} \mathrm{O}_{24}$, $15 \mu \mathrm{MH}_{3} \mathrm{BO}_{3}, 8 \mu \mathrm{M} \mathrm{MnCl}_{2}, 0.12 \mu \mathrm{M} \mathrm{CuSO}_{4}, 0.12 \mu \mathrm{M} \mathrm{ZnSO}_{4}, 29 \mu \mathrm{MFeCl}_{3}$, and $40.5 \mu \mathrm{M}$ citric acid, without $\left(\mathrm{NH}_{4}\right)_{2} \mathrm{SO}_{4}$ [61]. The $\mathrm{pH}$ of the culture solution was adjusted to 5.5 using $1 \mathrm{M} \mathrm{NaOH}$.

\subsection{RNA extracTion and Real-Time PCR}

The anatomical sample and ammonium response sample in rice were frozen in liquid nitrogen and ground with a Tissue Lyser II (Qiagen, Hilden, Germany). The RNA from both was extracted using the RNAiso Plus Kit, according to the manufacturer's protocol (Takara Bio, Kyoto, Japan). To determine the relative gene expression patterns by qRT-PCR, we used a primer set for rice ubiquitin 5 (OsUbi5, LOC_Os01g22490) [62]. For real-time $\mathrm{PCR}$, the cycling conditions were $95{ }^{\circ} \mathrm{C}$ for $9 \mathrm{~s}, 57^{\circ} \mathrm{C}$ for $10 \mathrm{~s}$, and $72{ }^{\circ} \mathrm{C}$ for $20 \mathrm{~s}$. All experiments were repeated three times using the same control primer sets and different biological replicates. All primers used in the qPCR analysis are described in Table S2.

\subsection{Genotyping of T-DNA Insertional Lines for the OsPIN1b Gene}

The ospin1b mutant, PFG_3A-04335, was obtained from RiceGE (http:/ / signal.salk. edu/cgi-bin/RiceGE accessed on 15 February 2021). The functional role of this gene has been reported previously [15]. To confirm the homozygous mutants by T-DNA insertion in the OsPIN1b gene, we genotyped the OsPIN1b-segregating population using a gene-specific primer set in a PCR assay. We also conducted an expression analysis of OsPIN1b in ospin1b mutants by qRT-PCR. All experiments were repeated three times using the same control primer sets and different biological replicates. All primer sequences used in the PCR and qPCR experiments are listed in Supporting Information Table S2.

\subsection{IAA Distribution Assay Using the DR5:GFP System (DR5::VENUS line) in Response to Ammonium}

To analyze the IAA distribution in rice under the ammonium response, we used DR5::VENUS reporter lines. First, the seeds of DR5::VENUS reporter lines were sterilized using 50\% bleach for 25 min with gentle shaking and then washed 4-5 times with sterile triple-distilled water. Subsequently, the reporter lines were germinated on MS solid medium and the seedlings were grown vertically for 10 days after germination. The seedlings were transferred to an $\mathrm{N}$-deficient solution $\left(0 \mathrm{mM}\left(\mathrm{NH}_{4}\right)_{2} \mathrm{SO}_{4}\right)$ for 3 days after 14 days in a hydroponic culture medium in distilled water. Half of the seedlings were 
grown under the same conditions with an $\mathrm{N}$-deficient solution $\left(0 \mathrm{mM}\left(\mathrm{NH}_{4}\right)_{2} \mathrm{SO}_{4}\right)$ for $48 \mathrm{~h}$, whereas the other half were transferred to an ammonium-supplemented solution $\left.\left(0.5 \mathrm{mM}\left(\mathrm{NH}_{4}\right)_{2} \mathrm{SO}_{4}\right)\right)$ and incubated for up to $48 \mathrm{~h}$. The tissues were photographed using a laser-scanning confocal microscope (Carl Zeiss, Jena, Germany).

\subsection{Measurement of Chlorophyll Content}

For chlorophyll measurements, approximately $50 \mathrm{mg}$ samples of fresh leaves were gathered from different $\mathrm{N}$ solutions (N-deficient $\left(0 \mathrm{mM}\left(\mathrm{NH}_{4}\right)_{2} \mathrm{SO}_{4}\right)$ and $\mathrm{N}$-sufficient $\left(0.5 \mathrm{mM}\left(\mathrm{NH}_{4}\right)_{2} \mathrm{SO}_{4}\right)$ solution) for $48 \mathrm{~h}$ after 17 days of $\mathrm{N}$-deprivation treatment. The anatomical sample and ammonium response sample in rice were frozen in liquid nitrogen, weighed, and ground with a Tissue Lyser II (Qiagen, Hilden, Germany). Chlorophyll was extracted with $80 \%$ aqueous acetone at $4{ }^{\circ} \mathrm{C}$ under darkness. The extract was measured spectrophotometrically at 645 and $663 \mathrm{~nm}$. A total amount of $80 \%$ aqueous acetone was used as a blank control. The chlorophyll content was calculated as described by [63].

\subsection{Measurement of Ammonium}

Plants were treated with ammonium responses from different $\mathrm{N}$ solutions $(-\mathrm{N}, \mathrm{N}$ deficient solution; $+\mathrm{N}, \mathrm{N}$-sufficient solution) for $3 \mathrm{~h}$ after 17 days of $\mathrm{N}$-deprivation treatment and soaked for $60 \mathrm{~min}$ in freshwater to remove extracellular NH4+. Samples were ground in liquid nitrogen after fresh-weight measurement (approximately $100 \mathrm{mg}$ ), extracted in $1 \mathrm{~mL}$ of $100 \mathrm{mM} \mathrm{HCl}$, and subsequently, $0.5 \mathrm{~mL}$ of chloroform was added. After centrifugation at $12,000 \times g$ for $10 \mathrm{~min}$ at $4{ }^{\circ} \mathrm{C}$, the supernatant was used for $\mathrm{NH} 4+$ concentration determination by phenol hypochlorite assay (Berthelot reaction). The following three solutions were added in the $200 \mu \mathrm{L}$ of tissue extract; $200 \mu \mathrm{L}$ of $11 \mathrm{mM}$ phenol in $95 \%$ $(v / v)$ ethanol;) $200 \mu \mathrm{L}$ of $1.7 \mathrm{mM}$ sodium nitroprusside; $500 \mu \mathrm{L}$ of the oxidizing solution containing $100 \mathrm{~mL}$ of $0.68 \mathrm{M}$ trisodium citrate in $0.25 \mathrm{M} \mathrm{NaOH}$ with $25 \mathrm{~mL}$ of sodium hypochlorite. The sample was incubated at $25^{\circ} \mathrm{C}$ for $90 \mathrm{~min}$ and absorbance was measured at $630 \mathrm{~nm}$. Three biological replicates of each of the three samples were analyzed. For each sample, two technical measures were recorded to check the accuracy, and the average of both measures was used. We conducted ammonium measurements according to [64] and [65].

Supplementary Materials: The following are available online at https:/ / www.mdpi.com/1422-006 7/22/6/3243/s1, Table S1. PIN-family genes of rice, Arabidopsis, and maize; Table S2. Summary of the primer sequences used for the qRT-PCR analyses in Figures 1, 3 and 6; Figure S1. Phylogenetic tree of rice, Arabidopsis, and maize PIN-family genes; Figure S2. Multiple alignment of PIN-family proteins in rice, Arabidopsis, and maize.

Author Contributions: Y.-S.G., M.-Y.S., D.-Y.B. and K.-H.J. conceived the research and designed the experiments. Y.-S.G., M.-Y.S., D.-Y.B. and H.C. performed the experiments. Y.-S.G., M.-Y.S., D.-Y.B. contributed materials. Y.-S.G., M.-Y.S., D.-Y.B. and K.-H.J. analyzed data and wrote the manuscript. All authors have read and agreed to the published version of the manuscript.

Funding: This work was supported by grants from the New Breeding Center Program (PJ01492703 to $\mathrm{KHJ}$ ), and The Collaborative Genome Program of the Korea Institute of Marine Science and Technology Promotion (KIMST) funded by the Ministry of Oceans and Fisheries (MOF) (No. 20180430 to K.-H.J).

Institutional Review Board Statement: Not available.

Informed Consent Statement: Not available.

Data Availability Statement: Not available.

Acknowledgments: We thank Gynheung An for providing seed of the T-DNA insertional line.

Conflicts of Interest: The authors declare no conflict of interest. 


$\begin{array}{ll}\text { Abbreviations } & \\ \text { AXR1 } & \text { Auxin-Resistant 1 } \\ \text { GDH } & \text { Glutamate Dehydrogenase } \\ \text { GS-GOGAT } & \text { Glutamine Synthase-Glutamate Synthase } \\ \text { IDD10 } & \text { Rice Ammonium Transporter 1;1 3 } \\ \text { OsAMT1;1 3 } & \text { Rice Asparagine Synthetase } \\ \text { OsAS2 } & \text { Rice Auxin Influx Carrier } \\ \text { OsAUX1 } & \text { Rice Glutamate Dehydrogenase } \\ \text { OsGDH2 } & \text { Rice endo-1, 4-b-D-glucanase 3 } \\ \text { OsGLU3 } & \text { Rice GLUTAMINE SYNTHETASE 1;2 } \\ \text { OsGS1;2 } & \text { Rice NADH Glutamate Synthase } \\ \text { OsNADH-GOGAT1 } & \text { Rice Auxin Efflux Carriers } \\ \text { OsPIN } & \text { Rice Ubiquitin 5 }\end{array}$

\section{References}

1. Wisniewska, J.; Xu, J.; Seifertova, D.; Brewer, P.B.; Ruzicka, K.; Blilou, I.; Rouquie, D.; Benkova, E.; Scheres, B.; Friml, J. Polar PIN localization directs auxin flow in plants. Science 2006, 312, 883. [CrossRef] [PubMed]

2. Petrasek, J.; Mravec, J.; Bouchard, R.; Blakeslee, J.J.; Abas, M.; Seifertova, D.; Wisniewska, J.; Tadele, Z.; Kubes, M.; Covanova, M.; et al. PIN proteins perform a rate-limiting function in cellular auxin efflux. Science 2006, 312, 914-918. [CrossRef] [PubMed]

3. Habets, M.E.; Offringa, R. PIN-driven polar auxin transport in plant developmental plasticity: A key target for environmental and endogenous signals. New Phytol. 2014, 203, 362-377. [CrossRef]

4. Omelyanchuk, N.A.; Kovrizhnykh, V.V.; Oshchepkova, E.A.; Pasternak, T.; Palme, K.; Mironova, V.V. A detailed expression map of the PIN1 auxin transporter in Arabidopsis thaliana root. BMC Plant Biol. 2016, 16, 5. [CrossRef]

5. Friml, J.; Benkova, E.; Blilou, I.; Wisniewska, J.; Hamann, T.; Ljung, K.; Woody, S.; Sandberg, G.; Scheres, B.; Jurgens, G.; et al. AtPIN4 mediates sink-driven auxin gradients and root patterning in Arabidopsis. Cell 2002, 108, 661-673. [CrossRef]

6. $\quad$ Robert, H.S.; Grones, P.; Stepanova, A.N.; Robles, L.M.; Lokerse, A.S.; Alonso, J.M.; Weijers, D.; Friml, J. Local auxin sources orient the apical-basal axis in Arabidopsis embryos. Curr. Biol. 2013, 23, 2506-2512. [CrossRef]

7. Mravec, J.; Skupa, P.; Bailly, A.; Hoyerova, K.; Krecek, P.; Bielach, A.; Petrasek, J.; Zhang, J.; Gaykova, V.; Stierhof, Y.D.; et al. Subcellular homeostasis of phytohormone auxin is mediated by the ER-localized PIN5 transporter. Nature 2009, 459, 1136-1140. [CrossRef]

8. Ding, Z.; Wang, B.; Moreno, I.; Duplakova, N.; Simon, S.; Carraro, N.; Reemmer, J.; Pencik, A.; Chen, X.; Tejos, R.; et al. ERlocalized auxin transporter PIN8 regulates auxin homeostasis and male gametophyte development in Arabidopsis. Nat. Commun. 2012, 3, 941. [CrossRef]

9. Simon, S.; Skupa, P.; Viaene, T.; Zwiewka, M.; Tejos, R.; Klima, P.; Carna, M.; Rolcik, J.; De Rycke, R.; Moreno, I.; et al. PIN6 auxin transporter at endoplasmic reticulum and plasma membrane mediates auxin homeostasis and organogenesis in Arabidopsis. New Phytol. 2016, 211, 65-74. [CrossRef] [PubMed]

10. Lu, G.; Coneva, V.; Casaretto, J.A.; Ying, S.; Mahmood, K.; Liu, F.; Nambara, E.; Bi, Y.M.; Rothstein, S.J. OsPIN5b modulates rice (Oryza sativa) plant architecture and yield by changing auxin homeostasis, transport and distribution. Plant J. 2015, 83, 913-925. [CrossRef] [PubMed]

11. Willige, B.C.; Isono, E.; Richter, R.; Zourelidou, M.; Schwechheimer, C. Gibberellin regulates PIN-FORMED abundance and is required for auxin transport-dependent growth and development in Arabidopsis thaliana. Plant Cell 2011, 23, 2184-2195. [CrossRef]

12. He, P.; Zhao, P.; Wang, L.; Zhang, Y.; Wang, X.; Xiao, H.; Yu, J.; Xiao, G. The PIN gene family in cotton (Gossypium hirsutum): Genome-wide identification and gene expression analyses during root development and abiotic stress responses. BMC Genom. 2017, 18, 507. [CrossRef] [PubMed]

13. Wang, Y.; Chai, C.; Valliyodan, B.; Maupin, C.; Annen, B.; Nguyen, H.T. Genome-wide analysis and expression profiling of the PIN auxin transporter gene family in soybean (Glycine max). BMC Genom. 2015, 16, 951. [CrossRef]

14. Li, S.-M.; Li, B.-Z.; Shi, W.-M. Expression patterns of nine ammonium transporters in rice in response to N status. Pedosphere 2012, $22,860-869$.

15. Kumar, A.; Silim, S.; Okamoto, M.; Siddiqi, M.; Glass, A. Differential expression of three members of the AMT1 gene family encoding putative high-affinity NH4+ transporters in roots of Oryza sativa subspecies indica. Plant Cell Environ. 2003, 26, 907-914. [CrossRef]

16. Suenaga, A.; Moriya, K.; Sonoda, Y.; Ikeda, A.; Von Wirén, N.; Hayakawa, T.; Yamaguchi, J.; Yamaya, T. Constitutive expression of a novel-type ammonium transporter OsAMT2 in rice plants. Plant Cell Physiol. 2003, 44, 206-211. [CrossRef] [PubMed]

17. Sonoda, Y.; Ikeda, A.; Saiki, S.; Wirén, N.V.; Yamaya, T.; Yamaguchi, J. Distinct expression and function of three ammonium transporter genes (OsAMT1; 1-1;3) in rice. Plant Cell Physiol. 2003, 44, 726-734. [CrossRef] 
18. Kumar, V.; Kim, S.-H.; Priatama, R.; Jeong, J.-H.; Adnan, M.; Saputra, B.A.; Han, C. NH 4+ Suppresses NO 3-Dependent Lateral Root Growth and Alters Gene Expression and Gravity Response in OsAMT1 RNAi Mutants of Rice (Oryza sativa). J. Plant Biol. 2020, 63, 391-407. [CrossRef]

19. Ireland, R. The enzymes of glutamine, glutamate, asparagine, and aspartate metabolism. Plant Amino Acids 1999, 2, 49-109.

20. Xu, G.; Fan, X.; Miller, A.J. Plant nitrogen assimilation and use efficiency. Annu. Rev. Plant Biol. 2012, 63, 153-182. [CrossRef]

21. Ishiyama, K.; Inoue, E.; Tabuchi, M.; Yamaya, T.; Takahashi, H. Biochemical background and compartmentalized functions of cytosolic glutamine synthetase for active ammonium assimilation in rice roots. Plant Cell Physiol. 2004, 45, 1640-1647. [CrossRef]

22. Brauer, E.K. Overexpression of cytosolic glutamine synthetase in rice improves utilization nitrogen use efficiency. Plant Physiol. 2009, 129, 1170-1180.

23. Tabuchi, M.; Abiko, T.; Yamaya, T. Assimilation of ammonium ions and reutilization of nitrogen in rice (Oryza sativa L.). J. Exp. Bot. 2007, 58, 2319-2327. [CrossRef] [PubMed]

24. Yamaya, T.; Kusano, M. Evidence supporting distinct functions of three cytosolic glutamine synthetases and two NADH-glutamate synthases in rice. J. Exp. Bot. 2014, 65, 5519-5525. [CrossRef]

25. Lee, S.; Marmagne, A.; Park, J.; Fabien, C.; Yim, Y.; Kim, S.J.; Kim, T.H.; Lim, P.O.; Masclaux-Daubresse, C.; Nam, H.G. Concurrent activation of OsAMT1; 2 and OsGOGAT1 in rice leads to enhanced nitrogen use efficiency under nitrogen limitation. Plant J. 2020, 103, 7-20. [CrossRef]

26. Kiba, T.; Kudo, T.; Kojima, M.; Sakakibara, H. Hormonal control of nitrogen acquisition: Roles of auxin, abscisic acid, and cytokinin. J. Exp. Bot. 2011, 62, 1399-1409. [CrossRef]

27. Sun, H.; Tao, J.; Bi, Y.; Hou, M.; Lou, J.; Chen, X.; Zhang, X.; Luo, L.; Xie, X.; Yoneyama, K.; et al. OsPIN1b is Involved in Rice Seminal Root Elongation by Regulating Root Apical Meristem Activity in Response to Low Nitrogen and Phosphate. Sci. Rep. 2018, 8, 13014. [CrossRef] [PubMed]

28. Cao, P.; Jung, K.-H.; Choi, D.; Hwang, D.; Zhu, J.; Ronald, P.C. The Rice Oligonucleotide Array Database: An atlas of rice gene expression. Rice 2012, 5, 17. [CrossRef]

29. Yang, J.; Yuan, Z.; Meng, Q.; Huang, G.; Perin, C.; Bureau, C.; Meunier, A.C.; Ingouff, M.; Bennett, M.J.; Liang, W.; et al. Dynamic Regulation of Auxin Response during Rice Development Revealed by Newly Established Hormone Biosensor Markers. Front. Plant Sci. 2017, 8, 256. [CrossRef] [PubMed]

30. Ohashi, M.; Ishiyama, K.; Kojima, S.; Konishi, N.; Nakano, K.; Kanno, K.; Hayakawa, T.; Yamaya, T. Asparagine synthetase1, but not asparagine synthetase2, is responsible for the biosynthesis of asparagine following the supply of ammonium to rice roots. Plant Cell Physiol. 2015, 56, 769-778. [CrossRef]

31. Zhang, J.; Xu, L.; Wang, F.; Deng, M.; Yi, K.J. Modulating the root elongation by phosphate/nitrogen starvation in an OsGLU3 dependant way in rice. Plant Signal. Behav. 2012, 7, 1144-1145. [CrossRef]

32. Balzan, S.; Johal, G.S.; Carraro, N. The role of auxin transporters in monocots development. Front. Plant Sci. 2014, 5, 393. [CrossRef] [PubMed]

33. Paponov, I.A.; Teale, W.D.; Trebar, M.; Blilou, I.; Palme, K. The PIN auxin efflux facilitators: Evolutionary and functional perspectives. Trends Plant Sci. 2005, 10, 170-177. [CrossRef]

34. Benkova, E.; Michniewicz, M.; Sauer, M.; Teichmann, T.; Seifertova, D.; Jurgens, G.; Friml, J. Local, efflux-dependent auxin gradients as a common module for plant organ formation. Cell 2003, 115, 591-602. [CrossRef]

35. Wang, J.R.; Hu, H.; Wang, G.H.; Li, J.; Chen, J.Y.; Wu, P. Expression of PIN genes in rice (Oryza sativa L.): Tissue specificity and regulation by hormones. Mol. Plant 2009, 2, 823-831. [CrossRef] [PubMed]

36. Xu, M.; Zhu, L.; Shou, H.; Wu, P. A PIN1 family gene, OsPIN1, involved in auxin-dependent adventitious root emergence and tillering in rice. Plant Cell Physiol. 2005, 46, 1674-1681. [CrossRef] [PubMed]

37. Cao, Y.; Glass, A.D.; Crawford, N.M. Ammonium inhibition of Arabidopsis root growth can be reversed by potassium and by auxin resistance mutations aux1, axr1, and axr2. Plant Physiol. 1993, 102, 983-989. [CrossRef] [PubMed]

38. Li, B.; Li, Q.; Su, Y.; Chen, H.; Xiong, L.; Mi, G.; Kronzucker, H.J.; Shi, W. Shoot-supplied ammonium targets the root auxin influx carrier AUX1 and inhibits lateral root emergence in Arabidopsis. Plant Cell Environ. 2011, 34, 933-946. [CrossRef]

39. Xuan, Y.H.; Kumar, V.; Zhu, X.F.; Je, B.I.; Kim, C.M.; Huang, J.; Cho, J.H.; Yi, G.; Han, C.D. IDD10 is Involved in the Interaction between NH 4+ and Auxin Signaling in Rice Roots. J. Plant Biol. 2018, 61, 72-79. [CrossRef]

40. Liu, B.; Zhang, J.; Wang, L.; Li, J.; Zheng, H.; Chen, J.; Lu, M. A survey of Populus PIN-FORMED family genes reveals their diversified expression patterns. J. Exp. Bot. 2014, 65, 2437-2448. [CrossRef] [PubMed]

41. Hanzawa, T.; Shibasaki, K.; Numata, T.; Kawamura, Y.; Gaude, T.; Rahman, A. Cellular auxin homeostasis under high temperature is regulated through a SORTING NEXIN1-dependent endosomal trafficking pathway. Plant Cell 2013, 25, 3424-3433. [CrossRef]

42. Bonser, A.M.; Lynch, J.; Snapp, S. Effect of phosphorus deficiency on growth angle of basal roots in Phaseolus vulgaris. New Phytol. 1996, 132, 281-288. [CrossRef]

43. Sun, F.; Zhang, W.; Hu, H.; Li, B.; Wang, Y.; Zhao, Y.; Li, K.; Liu, M.; Li, X. Salt modulates gravity signaling pathway to regulate growth direction of primary roots in Arabidopsis. Plant Physiol. 2008, 146, 178-188. [CrossRef]

44. Fasano, J.M.; Massa, G.D.; Gilroy, S. Ionic signaling in plant responses to gravity and touch. J. Plant Growth Regul. 2002, 21, 71-88. [CrossRef] 
45. Zou, N.; Li, B.; Dong, G.; Kronzucker, H.J.; Shi, W. Ammonium-induced loss of root gravitropism is related to auxin distribution and TRH1 function, and is uncoupled from the inhibition of root elongation in Arabidopsis. J. Exp. Bot. 2012, 63, 3777-3788. [CrossRef]

46. Rigas, S.; Ditengou, F.A.; Ljung, K.; Daras, G.; Tietz, O.; Palme, K.; Hatzopoulos, P. Root gravitropism and root hair development constitute coupled developmental responses regulated by auxin homeostasis in the Arabidopsis root apex. New Phytol. 2013, 197, 1130-1141. [CrossRef] [PubMed]

47. Blilou, I.; Xu, J.; Wildwater, M.; Willemsen, V.; Paponov, I.; Friml, J.; Heidstra, R.; Aida, M.; Palme, K.; Scheres, B. The PIN auxin efflux facilitator network controls growth and patterning in Arabidopsis roots. Nature 2005, 433, 39-44. [CrossRef] [PubMed]

48. Vieten, A.; Vanneste, S.; Wiśniewska, J.; Benková, E.; Benjamins, R.; Beeckman, T.; Luschnig, C.; Friml, J. Functional redundancy of PIN proteins is accompanied by auxin-dependent cross-regulation of PIN expression. Development 2005, 132, 4521-4531. [CrossRef] [PubMed]

49. Blanke, M.M.; Bacher, W.; Pring, R.J.; Baker, E.A. Ammonium nutrition enhances chlorophyll and glaucousness in kohlrabi. Ann. Bot. 1996, 78, 599-604. [CrossRef]

50. Kant, S.; Rothstein, S. Auxin-responsive SAUR39 gene modulates auxin level in rice. Plant Signal. Behav. 2009, 4, 1174-1175. [CrossRef] [PubMed]

51. Masclaux-Daubresse, C.; Reisdorf-Cren, M.; Pageau, K.; Lelandais, M.; Grandjean, O.; Kronenberger, J.; Valadier, M.-H.; Feraud, M.; Jouglet, T.; Suzuki, A. Glutamine synthetase-glutamate synthase pathway and glutamate dehydrogenase play distinct roles in the sink-source nitrogen cycle in tobacco. Plant Physiol. 2006, 140, 444-456. [CrossRef]

52. Lasa, B.; Frechilla, S.; Aparicio-Tejo, P.M.; Lamsfus, C. Role of glutamate dehydrogenase and phosphoenolpyruvate carboxylase activity in ammonium nutrition tolerance in roots. Plant Physiol. Biochem. 2002, 40, 969-976. [CrossRef]

53. Xuan, Y.H.; Priatama, R.A.; Kumar, V.; Han, C.D. Regulatory role of indeterminate domain 10 (IDD10) in ammonium-dependent gene expression in rice roots. Plant Signal. Behav. 2013, 8, e24139. [CrossRef] [PubMed]

54. Zhang, J.W.; Xu, L.; Wu, Y.R.; Chen, X.A.; Liu, Y.; Zhu, S.H.; Ding, W.N.; Wu, P.; Yi, K.K. OsGLU3, a putative membrane-bound endo-1,4-beta-glucanase, is required for root cell elongation and division in rice (Oryza sativa L.). Mol. Plant 2012, 5, 176-186. [CrossRef] [PubMed]

55. Kumar, S.; Stecher, G.; Tamura, K. MEGA7: Molecular Evolutionary Genetics Analysis Version 7.0 for Bigger Datasets. Mol. Biol. Evol. 2016, 33, 1870-1874. [CrossRef]

56. Gho, Y.-S.; Choi, H.; Moon, S.; Song, M.-Y.; Park, H.-E.; Kim, D.-H.; Ha, S.-H.; Jung, K.-H. Phosphate-starvation-inducible S-like RNase genes in rice are involved in phosphate source recycling by RNA decay. Front. Plant Sci. 2020, 11, 585561. [CrossRef] [PubMed]

57. Thompson, J.D.; Gibson, T.J.; Higgins, D.G. Multiple sequence alignment using ClustalW and ClustalX. Curr. Protoc. Bioinform. 2002, 1, 2-3. [CrossRef] [PubMed]

58. Jung, K.-H.; Cao, P.; Seo, Y.-S.; Dardick, C.; Ronald, P.C. The Rice Kinase Phylogenomics Database: A guide for systematic analysis of the rice kinase super-family. Trends Plant Sci. 2010, 15, 595-599. [CrossRef] [PubMed]

59. Moon, S.; Chandran, A.K.N.; Kim, Y.-J.; Gho, Y.; Hong, W.-J.; An, G.; Lee, C.-H.; Jung, K.-H. Rice RHC encoding a putative cellulase is essential for normal root hair elongation. J. Plant Biol. 2019, 62, 82-91. [CrossRef]

60. Kim, E.-J.; Kim, Y.-J.; Hong, W.-J.; Lee, C.; Jeon, J.-S.; Jung, K.-H. Genome-wide analysis of root hair preferred RBOH genes suggests that three RBOH genes are associated with auxin-mediated root hair development in rice. J. Plant Biol. 2019, 62, 229-238. [CrossRef]

61. Chandran, A.K.N.; Priatama, R.A.; Kumar, V.; Xuan, Y.; Je, B.I.; Kim, C.M.; Jung, K.-H.; Han, C.-D. Genome-wide transcriptome analysis of expression in rice seedling roots in response to supplemental nitrogen. J. Plant Physiol. 2016, 200, 62-75. [CrossRef] [PubMed]

62. Gho, Y.-S.; An, G.; Park, H.-M.; Jung, K.-H. A systemic view of phosphate starvation-responsive genes in rice roots to enhance phosphate use efficiency in rice. Plant Biotech. Rep. 2018, 12, 249-264. [CrossRef]

63. Arnon, D.-I. Copper enzymes in isolated chloroplasts. Polyphenoloxidase in Beta vulgaris. Plant Physiol. 1949, 24, 1-15. [CrossRef] [PubMed]

64. Bräutigam, A.; Gagneul, D.; Weber, A.P. High-throughput colorimetric method for the parallel assay of glyoxylic acid and ammonium in a single extract. Anal. Biochem. 2007, 362, 151-153. [CrossRef]

65. Hachiya, T.; Okamoto, Y. Simple spectroscopic determination of nitrate, nitrite, and ammonium in Arabidopsis thaliana. Bio Protoc. 2017, 7, e2280. [CrossRef] 